\title{
ANALISIS EKONOMI ISLAM TERHADAP PEMENUHAN UPAH LAYAK TENAGA KERJA INDUSTRI BATIK (STUDI KASUS SENTRA BATIK KECAMATAN PLERED KABUPATEN CIREBON)
}

\author{
Nono Hartono \\ Sekolah Tinggi Ekonomi Islam (STEI) Al-Ishlah Cirebon \\ Email: khalidbinwalid1435@gmail.com
}

\begin{abstract}
:
Batik industry was an excellent product of Plered that have been set by the Government, especially Cirebon. Cirebon Regency was the largest industrial centers batik in West Java, because many industry batik in Plered and many people worked as batik artisans in Plered. The existence of an industry is expected to have many benefits not only for the manufacturers but also for its workforce. The purpose of this research was (1)ldentifying the wages received by the batik industry workforce housing units has met the needs of the eligible. (2) Analyze the Economic Outlook of the Islamic labor waging system unit home batik Subdistrict Plered (3) Composing model waging a be eligible on batik home Sub unit Plered. This research used purposive sampling with population of batik industry is a labor of a home unit. Analytical tool used was Multiple Linear Regression. Results the regression show that factors that influence significantly to levels of wage labor unit home batik industry is a long work day, work experience and operational cost, whereas other variables was not significant. Therefore, to increase the wages in order to acquire the necessary life worthy remuneration models that were eligible on the batik industry, are with a view to the verses that have been described in the Qur'an. Wage system that occurred in the housing unit labor could be said to be in accordance with the provisions of the contract of ljarah, although the amount is not yet worthy but it is in conformity with the customs and traditions in the society Plered and workers batik housing unit no matter anything, as well as the delay in wages
\end{abstract}

Keywords: Labor Housing Units, Minimum Wage, Multiple Linear Regression, Needs Decent Living.

\section{PENDAHULUAN}

Cirebon dikenal sebagai kota udang dan kota wali merupakan daerah berkembang yang letaknya sangat strategis, yaitu terletak jalur Pantura (Pantai Utara). Karena lokasi geografisnya, Cirebon menjadi salah satu jalur utama yang menghubungkan antara Kota Jakarta-Semarang-Surabaya. Cirebon juga merupakan salah satu daerah industri yang ada di Jawa Barat, salah satu industri yang sekarang berkembang dengan pesat yaitu terletak di Kabupaten Cirebon, dengan komoditas unggulannya batik. Industri batik yang ada di Kecamatan Plered sendiri ditetapkan oleh
Pemerintah Kabupaten Cirebon sebagai sentra industri batik terbesar di Jawa Barat, hal ini dikarenakan banyak berdirinya industri batik yang ada di Kecamatan Plered dan sudah menjadi budaya membatik bagi masyarakat sekitar. Tentunya dengan berdirinya industri tersebut memberi dampak yang cukup positif terhadap perekonomian masyarakat sekitar, terutama pada kalangan buruh, karena dapat memberi peluang kerja demi keberlangsungan hidup masyarakat.

Keberadaan suatu industri diharapkan memiliki banyak manfaat tak hanya bagi pemilik industri namun untuk 
Hartono/Jurnal Ekonomi Syariah Teori dan Terapan Vol. 6 No. 4 April 2019: 861-879; ANALISIS EKONOMI ISLAM TERHADAP PEMENUHAN UPAH LAYAK TENAGA KERJA INDUSTRI BATIK (STUDI KASUS : SENTRA BATIK KECAMATAN PLERED KABUPATEN CIREBON)

tenagakerjanya juga. Dimana pekerja berperan penting dalam suatu industri yaitu pekerja menggunakan tenaga kemampuannya untuk mendapatkan balasan berupa upah baik berupa vang maupun bentuk lainnya. Kebijakan ketenagakerjaan sudah diatur oleh Pemerintah terutama menyangkut penanganan pengupahan yang disebut Kebutuhan Hidup Layak (KHL). Berkaitan dengan kebutuhan kehidupan layak pekerja, maka tidak akan lepas dari permasalahan upah. Masalah upah yang diambil dalam penelitian ini yaitu adanya ketidak adilan dan keterlambatanm dalam pengupahan.

Adapun menurut narasumber yang didapatkan ketika observasi pendahuluan yakni pekerja unit rumahan ibu Antini (Nembok), beliau menjelaskan bahwa untuk satu kain harus menyelesaikan dalam waktu satu setengah hari dan upah yang diterima senilai Rp 25.000,- dalam sehari menghabiskan waktu 8 jam, jadi untuk menyelasaikan satu kain batik tersebut membutuhkan waktu 12 jam, adapun untuk peralatan yang digunakan untuk membatik dan bahan bakar yang digunakan sudah menjadi tanggungjawab pekerja, dalam sehari pekerja harus menghabiskan bahan bakar setengah liter untuk harga 1 liternya Rp 7.000,- Jika dikalkulasikan pendapatan pekerja yang diterima untuk satu kain yaitu: $\begin{array}{ll}\text { Kain @ 1 potong } & =\operatorname{Rp~25.000,-} \\ \text { Bahan bakar } 1 / 2 \text { liter } & =\frac{\operatorname{Rp~3.500,---}}{\operatorname{Rp~} 21.500,- \text { / } 12 \mathrm{jam}}\end{array}$

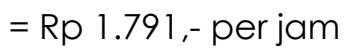

Jadi untuk satu jam, pekerja menerima upah sebesar $\mathrm{Rp}$ 1.791,kemudian masalah dalam membatik sendiri sering dialami oleh pekerja ketika lilin yang terpakai kurang atau tidak mencukupi maka harus membeli lilin dan itupun sudah menjadi tanggungjawab pekerja, selain itu dalam menerima upah, pekerja harus menunggu batik tersebut jadi atau sudah siap pakai.

Berdasarkan Upah Minimum Kerja (UMK) Kabupaten Cirebon tahun 2016, diperoleh sebuah keterangan bahwa gaji atau upah minimum Kabupaten Cirebon adalah Rp 1.592.220,- penentuan hasil tersebut berdasarkan rumus yang mengacu pada Peraturan Pemerintah (PP) nomor 78 tahun 2015, yaitu perhitungannya UMK tahun 2015 sebesar Rp 1.428.000,- ditambah Rp 164.220,- atau $12 \%$ dari UMK tahun 2015. Hal ini menandakan gaji tersebut harus diterima utuh bagi pekerja atau buruh, karena ini merupakan haknya dan apabila jumlah tersebut tidak diterima secara utuh atau kurang oleh pekerja maka ketimpangan akan timbul. Oleh karena itu untuk melindungi kepentingan dari pelanggaran hak perlu ditentukan upah minimum sehingga pekerja akan memperoleh kehidupan yang layak.

Untuk Kebutuhan Hidup Layak (KHL) Pemerintah mengeluarkan 
Kebijakan, seperti yang telah diamanatkan dalam Pasal dapat dilihat dari Pasal 88 ayat (1) Undang-Undang yang menegaskan bahwa "Setiap pekerja berhak memperoleh penghasilan yang memenuhi penghidupan yang layak bagi kemanusiaan." Kebutuhan Hidup Layak (KHL) UU tersebut mencakup kebutuhan pokok hidup, termasuk makanan, pakaian, tempat tinggal dan lainnya, sehingga pekerja akan memperoleh kehidupan yang layak. Adapun dalam pandangan islam upah tidak sekedar kebutuhan lahir saja, tetapi mereka harus mendapatkan pendidikan dan berbagai fasilitas pengobatan. Sehingga apabila upah dikaitkan dengan apa yang telah difasilitaskan atau sesuai kebutuhan minimalnya adalah sangat tidak tepat karena akan menghalangi pekerja untuk menikmati kehidupan yang layak menurut ukuran masyarakat. Penelitian ini bertujuan (1) mengidentifikasi apakah upah yang diterima pihak tenaga kerja industri batik unit rumahan telah memenuhi kebutuhan yang layak; (2) menganalisis pandangan ekonomi islam terhadap sistem pengupahan tenaga kerja unit rumahan industri batik di Kecamatan Plered; dan (3) menyusun model pengupahan yang layak pada industri batik unit rumahan Kecamatan Plered.

\section{LANDASAN TEORI}

\section{Upah Tenaga Kerja}

Upah dalam bahasa Arab sering disebut dengan ajrun/ajran yang berarti memberi hadiah/upah. Kata ajran mengandung dua arti, yaitu balasan atas pekerjaan dan pahala. Sedangkan upah menurut istilah adalah vang dan sebagainya yang dibayarkan sebagai balas jasa atau bayaran atas tenaga yang telah dicurahkan untuk mengerjakan sesuatu. Upah diberikan sebagai balas jasa atau penggantian kerugian yang diterima oleh pihak pekerja karena atas pencurahan tenaga kerjanya kepada orang lain yang berstatus sebagai majikan.

Menurut Mustofa (2009) sumber hukum dalam islam yang dipakai dalam menyelesaikan berbagai permasalahan yang terjadi adalah dengan menggunakan Al-Qur'an dan Sunah Nabi, disamping masih banyak lagi sumber hukum yang dapat digunakan. Al-Qur'an sebagai sumber hukum upah salah satunya diambil dari Al-Qur'an Qs.AlAhqaf ayat 19. Artinya:

"Dan bagi masing-masing mereka derajat menurut apa yang Telah mereka kerjakan dan agar Allah mencukupkan bagi mereka (balasan) pekerjaanpekerjaan mereka sedang mereka tiada dirugikan."

Berdasarkan ayat Al-Qur'an diatas, menunjukkan bahwa upah telah disyari'atkan oleh Allah dan wajib dibayarkan sebagai kompensasi atau balasan dan sekaligus merupakan hak bagi pekerja atau buruh dengan cara menjunjung tinggi nilai-nilai keadilan dan kelayakan sesuatu dengan bantuan atau 
tenaga yang telah diberikan oleh pekerja. Akan tetapi islam menolak anggapan bahwa bekerja bukan hanya sematamata untuk mendapatkan imbalan yang bersifat materi saja, akan tetapi untuk mendapatkan pahala seperti yang diungkapkan oleh sayyid Qutub "Keadilan yang mutlak pasti membutuhkan perbedaan imbalan ada kelebihan sebagian dari sebagian yang lainnya, disamping realisasi keadilan dari segi kemanusiaan, berupa pemberian kesempatan yang merata dan meluas kepada masyarakat islam menolak menjadikan materi sebagai imbalan bagi nilai-nilai itu (bekerja) dan tidak mau mengubah (merubah-pen) kehidupan ini menjadi sekedar nilai dengan sepotong roti, kepuasan jasmani/sejumlah uang".

\section{Tingkatan dalam Pemberian Upah}

Dalam hal tingkatan dalam pemberian upah, ada beberapa faktor yang menyebabkan perbedaannya dalam kehidupan berindustri, diantaranya mengacu pada bakat dan ketrampilan seorang pekerja. Adanya pekerja intelektual dan pekerja kasar atau pekerja yang handal dengan pekerja yang tidak handal, mengakibatkan upah berbeda tingkatannya. Selain itu perbedaan upah yang timbul karena perbedaan keuntungan yang tidak berupa uang karena ketidaktahuan atau kelambanan dalam bekerja dan masih banyak lagi faktor-faktor lainnya. Mengenai perbedaan upah islam mengakui adanya perbedaan kemampuan dan bakat yang dimiliki masing-masing pekerja. Adapun dalil yang dipergunakan sebagai landasannya adalah firman Allah SWT Qs.An-Nisa ayat 32 yang berbunyi:

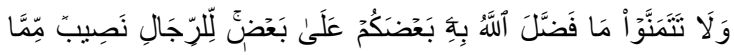

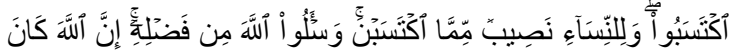

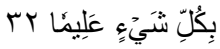
Artinya: "Dan janganlah kamu iri hati terhadap apa yang dikaruniakan Allah kepada sebahagian kamu lebih banyak dari sebahagian yang lain. (karena) bagi orang laki-laki ada bahagian dari pada apa yang mereka usahakan, dan bagi para wanita (pun) ada bahagian dari apa yang mereka usahakan, dan mohonlah kepada Allah sebagian dari karunia-Nya. Sesungguhnya Allah Maha mengetahui segala sesuatu."

Adapun berdasarkan prinsip keadilan upah dalam islam ditetapkan kesepakatan antara majikan dan pekerja dengan menjaga kepentingan keduanya, mengingat posisi pekerja yang lemah, maka islam memberikan perhatian dengan menetapkan tingkat upah minimum bagi pekerja sesuai dengan prinsip kelayakan dari upah. Upah itu menjadi tanggungjawab negara untuk mempertimbangkan tingkat upah agar tidak terlalu rendah sehingga kebutuhan pekerja tidak tercukupi, namun juga tidak terlalu tinggi sehingga kehilangan bagian dari hasil kerjasama itu.

Tingkat upah minimum ditentukan dengan memperhatikan perubahan kebutuhan dari pekerja golongan bawah, sehingga dalam kondisi apapun tingkat 
upah ini tidak akan jatuh. Perkiraan besarnya upah diukur besarnya berdasarkan kadar jasa yang diberikan tenaga kerja, berdasarkan kesepakatan dari orang yang bertransaksi dan adakalanya ditentukan oleh para ahli sesuai dengan manfaat serta waktu yang tepat dimana pekerjaan itu dilakukan. Sehingga pada suatu saat akan mengalami revisi sesuai dengan tuntutan jaman.

Pekerja yang bekerja disebuah industri tidak secara sukarela ingin bekerja disuatu industri. Tentunya mereka akan memiliki motivasi mengapa mereka memilih bekerja disebuah industri tersebut. namun, salah satu motivasi utamanya adalah mendapatkan upah yang tinggi. Besarnya upah, didasarkan pada besarnya upah disuatu wilayah atau sering disebut sebagai upah minimum.

\section{Tingkat Upah Minimum}

Pekerja dalam hubungannya dengan majikan berada dalam posisi yang sangat lemah. Selalu ada kemungkinan kepentingan para pekerja tidak dilindungi dengan baik. Mengingat posisinya yang lemah itu, Islam memberikan perhatian dalam melindungi hak para pekerja dari segala gangguan yang dilakukan oleh majikannya. Oleh karena itu untuk melindungi kepentingan dari pelanggaran hak perlu ditentukan upah minimum yang dapat mencakup kebutuhan pokok hidup, termasuk makanan, pakaian, tempat tinggal dan lainnya, sehingga pekerja akan memperoleh kehidupan yang laik.

Negara mempunyai peranan yang sangat penting, yaitu memperhatikan agar setiap pekerja memperoleh upah yang cukup untuk mempertahankan suatu tingkat kehidupan yang wajar serta tidak memperoleh upah dibawah tingkat minimum. Tingkat upah minimum ini harus selalu dan sewaktu-waktu direvisi kembali untuk melakukan penyesuaian tingkat harga dan biaya hidup dalam masyarakat.

\section{Tingkat Upah Tertinggi}

Bakat dan ketrampilan seorang pekerja meruapakan salah satu fakor upahnya tinggi atu tidak. Pekerja yang intelektual dengan pekerja kasar atau pekerja yang handal dengan pekerja yang tidak handal, mengakibatkan upah berbeda tingkatnya. Selain itu perbedaan upah timbul karena perbedaan keuntungan yang tidak berupa uang, karena ketidak tahuan atau kelambanan dalam bekerja dan masih banyak lagi faktor-faktornya. Oleh karena itu, Islam memang tidak memberikan upah berada dibawah upah minimum yang telah ditetapkan, demikian halnya Islam juga tidak membolehkan kenaikan upah melebihi tingkat tertentu melebihi sumbangsih dalam produksinya. Oleh karena itu, tidak perlu terjadi kenaikan upah yang melampaui batas tertinggi dalam penentuan batas maksimum upah tersebut. setidaknya upah dapat memenuhi kebutuhan poko pekerja dan 
Hartono/Jurnal Ekonomi Syariah Teori dan Terapan Vol. 6 No. 4 April 2019: 861-879; ANALISIS EKONOMI ISLAM TERHADAP PEMENUHAN UPAH LAYAK TENAGA KERJA INDUSTRI BATIK (STUDI KASUS : SENTRA BATIK KECAMATAN PLERED KABUPATEN CIREBON)

kelvarga agar tercipta keadilan dan pemerataan kesejahteraan. Pentingnya menjaga upah agar tetap berada pada batas kewajaran agar masyarakat tidak cenderung menjadi mengkonsumsi semua barang konsumsi. Gambaran tentang batas upah tertinggi dapat dilihat pada ayat Al-Qur'an Qs.An-Najm ayat 39:

Artinya: Dan bahwasanya seorang manusia tiada memperoleh selain apa yang Telah diusahakannya,

Dalam ayat lainnya juga disebutkan Qs.An-Nahl ayat 96:

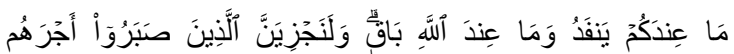

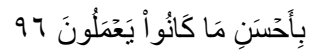

Artinya: Apa yang di sisimu akan lenyap, dan apa yang ada di sisi Allah adalah kekal. dan Sesungguhnya kami akan memberi balasan kepada orang-orang yang sabar dengan pahala yang lebih baik dari apa yang Telah mereka kerjakan.

Ayat di atas menjelaskan bahwa upah yang dituntut oleh para pekerja dari majikan harus sesuai dengan apa yang telah diusahakannya, bersama kegiatankegiatan manusia yang telah berhubungan dengan ketenagakerjaan. Sudah menjadi kewajiban bagi setiap majikan untuk memberikan upah yang baik dan cukup bagi para pekerjanya agar mereka dapat menikmati kehidupan yang menyenangkan. Berdasarkan uraian diatas dapatlah disimpulkan bahwa batasan mengenai upah tertinggi adalah sesuai dengan apa yang telah dikerjakan. Adapun besarnya tingkat upah maksimum pekerja akan bervariasi berdasarkan jasa yang disumbangkan dalam produksi.

\section{Tingkat Upah Sebenarnya}

Islam telah menyediakan usaha pengamanan untuk melindungi hak majikan dan pekerja. Jatuhnya upah dibawah tingkat upah minimum atau naiknya upah melebihi batas upah maksimum seharusnya tidak terjadi. Upah yang sesungguhnya akan berubah dengan sendirinya berdasarkan hukum penawaran dan permintaan tenaga kerja, yang sudah tentu dipengaruhi oleh standar hidup pekerja, kekuatan efektif dari organisasi pekerja, serta sikap para majikan yang mencerminkan keimanan mereka terhadap balasan Allah SWT.

Sebagai hasil interaksi antara kedua kekuatan antara majikan dan ruh, maka upah akan berada diantara upah minimum dan maksimum yang mengacu pada taraf hidup yang lazim serta berkontribusi yang telah diberikan para pekerja. Jika pada suatu waktu upah minimum jatuh dibawah tingkat minimum ataupun sebaliknya, maka negara berhak melakukan campur tangan dan menetapkan upah sesuai dengan kebutuhan saat itu. Sehingga dapat disimpulkan bahwa tingkat upah sebenarnya akan berkisar antara kedua batas upah berdasarkan hukum persediaan dan penawaran tenaga kerja dan dipengaruhi oleh standar hidup sehari-hari kelompok kerja, sebagai hasilnya tingkat upah minimum dan 
Hartono/Jurnal Ekonomi Syariah Teori dan Terapan Vol. 6 No. 4 April 2019: 861-879; ANALISIS EKONOMI ISLAM TERHADAP PEMENUHAN UPAH LAYAK TENAGA KERJA INDUSTRI BATIK (STUDI KASUS : SENTRA BATIK KECAMATAN PLERED KABUPATEN CIREBON)

maksimum akan ditetapkan berdasarkan standar hidup kelompok pekerja dan tetap merangkak naik sesuai dengan naiknya standar hidup tersebut.

\section{Kebutuhan Hidup Layak}

Pemerintah Indonesia selalu berubah-ubah kebijakan

ketenagakerjaannya terutama menyangkut penanganan pengupahan. Kebijakan penentuan upah minimum didasarkan pada Kebutuhan Fisik Minimum (KFM), yang kemudian berubah menjadi Kebutuhan Hidup Minimum (KHM), lalu sekarang namanya menjadi Kebutuhan Hidup Layak (KHL). Seperti yang telah diamanatkan dalam Pasal 89 ayat (2) Undang-Undang Nomor 13 Tahun 2003 tentang ketenagakerjaan. Sementara kaitannya dengan Kebutuhan Hidup Layak, dapat dilihat dari Pasal 88 ayat (1) Undang-Undang yang sama yang menegaskan bahwa setiap pekerja berhak memperoleh penghasilan yang memenuhi penghidupan yang memenuhi penghidupan yang layak bagi kemanusiaan.

Berkaitan dengan penetapan upah berdasarkan Kebutuhan Hidup Layak (KHL), Pemerintah menetapkan peraturan atau yang dikenal dengan Permenakertrans Nomor: PER17/MEN/VIII/2005 tentang Komponen dan Pelaksanaan Tahapan Pencapaian Kebutuhan Hidup Layak (KHL) sekaligus sebagai aturan dalam pelaksanaan dari Pasal 89 ayat (4) Undang-Undang Nomor 13 Tahun 2003 tentang Ketenagakerjaan yang berbunyi: Komoponen dan pelaksanaan tahapan pencapaian kebutuhan hidup layak diatur dengan Peraturan Menteri. Dalam Pasal 1 Permenakertrans Nomor: PER17/MEN/VIII/2005 misalnya disebutkan bahwa KHL adalah Standar kebutuhan yang harus dipenuhi oleh seorang pekerja atau buruh lajang untuk dapat hidup layak baik secara fisik, non fisik dan sosial untuk kebutuhan satu bulan. Komponen kebutuhan hidup layak untuk para pekerja lajang dalam satu bulan sebagaimana terlampir dalam Nomor: PER17/MEN/VIII/2005 terdiri dari: makanan dan minuman, sandang, perumahan, pendidikan, kesehatan, transportasi dan rekreasi dan tabungan.

\section{Adapun menurut Muhammad} Mustofa (2009) islam memberikan pedoman bagi kehidupan manusia dalam bidang perekonomian tidak memberikan landasan yang bersifat praktis, berapa besarnya upah yang harus diberikan kepada pekerja untuk mencukupi kebutuhan hidup. Namun islam memperbolehkan seseorang untuk mengontrak tenaga pekerja agar mereka bekerja untuk orang tersebut, sebagaimana dalam Al-Qur'an disebutkan Qs.Az-Zukhruf:32:

Artinya: "Apakah mereka yang membagibagi rahmat Tuhanmu? Kami telah menentukan antara mereka penghidupan mereka dalam kehidupan dunia, dan Kami telah meninggikan sebahagian mereka atas sebagian yang lain 
Hartono/Jurnal Ekonomi Syariah Teori dan Terapan Vol. 6 No. 4 April 2019: 861-879; ANALISIS EKONOMI ISLAM TERHADAP PEMENUHAN UPAH LAYAK TENAGA KERJA INDUSTRI BATIK (STUDI KASUS : SENTRA BATIK KECAMATAN PLERED KABUPATEN CIREBON)

beberapa derajat, agar sebagian mereka dapat mempergunakan sebagian yang lain. dan rahmat Tuhanmu lebih baik dari apa yang mereka kumpulkan."

Berkaitan dengan kebutuhan hidup layak pekerja, maka tidak akan lepas dari permasalahan upah. Masalah upah sangat penting dan dampaknya sangat luas. Jika pekerja tidak menerima upah yang adil dan pantas, itu tidak hanya akan mempengaruhi daya beli yang akhirnya mempengaruhi standar penghidupan para pekerja beserta keluarga mereka, melainkan akan langsung mempengaruhi seluruh masyarakat karena mereka mengkonsumsi sejumlah besar produksi negara.

\section{Telaah Penelitian Terdahulu}

1. Pada penelitian yang dilakukan Hafidh pada tahun 2014 yang menjadi objek penelitian adalah Industri Tekstil di Kecamatan Pedurungan Kota Semarang, yang diteliti berupa faktorfaktor yang mempengaruhi tingkat upah tenagakerja terdapat 6 variabel yaitu jumlah jam kerja, sistem kerja, jumlah tanggungan, lama kerja, tingkat pendidikan dan jenis kelamin.

2. Pada penelitian yang dilakukan Sa'adah pada tahun 2014, yang menjadi objek penelitian adalah tenaga kerja di PT Aspex Kumbong guna mencapai pemenuhan kebutuhan hidup layak, yang diteliti mengenai kompensasi khususnya komponen kebutuhan hidup layak, dalam hal sistem pengupahan dan kelayakan upah yang diterima dalam memenuhi kebutuhan hidup pekerja serta pembentuk upah minimum dalam menggambarkan standar kehidupan layak pekerja.

\section{METODE PENELITIAN}

\section{Desain Penelitian}

Dalam pelaksanaan penelitian ini menggunakan metode dekriptif, yaitu menurut Nasir (1988), metode deskriptif merupakan suatu metode dalam meneliti status sekelompok manusia, suatu objek, suatu set kondisi, suatu sistem pemikiran ataupun suatu kelas peristiwa pada masa sekarang. Penelitian ini juga menggunakan pendekatan kuantitatif, yaitu data penelitian berupa angka dan analisis menggunakan statistik data sekunder yaitu data penelitian yang diperoleh secara tidak langsung melalui media perantara.

\section{Populasi dan Sampel}

Menurut Sugiyono (2012) populasi adalah wilayah generalisasi yang terdiri atas obyek/subyek yang mempunyai kualitas dan karakteristik tertentu yang ditetapkan oleh peneliti untuk dipelajari dan kemudian ditarik kesimpulannya. Populasi dari penelitian ini adalah masyarakat yang ikut berkontribusi dalam proses produksi batik di Kecamatan Plered.

Tabel 1.

Jumlah Tenaga Kerja Industri Batik di Kecamatan Plered

\begin{tabular}{|l|l|c|}
\hline No & Nama Desa & Tenaga Kerja (Orang) \\
\hline 1. & Trusmi Kulon & 450 \\
\hline
\end{tabular}


Hartono/Jurnal Ekonomi Syariah Teori dan Terapan Vol. 6 No. 4 April 2019: 861-879; ANALISIS EKONOMI ISLAM TERHADAP PEMENUHAN UPAH LAYAK TENAGA KERJA INDUSTRI BATIK (STUDI KASUS : SENTRA BATIK KECAMATAN PLERED KABUPATEN CIREBON)

\begin{tabular}{|c|l|c|}
\hline 2. & Trusmi Wetan & 200 \\
\hline 3. & Panembahan & 120 \\
\hline 4. & Gamel & 40 \\
\hline 5. & Wotgali & 39 \\
\hline & Jumlah & $\mathbf{8 4 9}$ \\
\hline
\end{tabular}

Sumber: Dinas Perindustrian dan

Perdagangan Kabupaten Cirebon, 2011

Pengambilan sampel pada penelitian ini dilakukan dengan menggunakan metode purposive sampling, yaitu pemilihan sampel secara sengaja artinya pemilihan sampel ditentukan sendiri oleh peneliti karena pertimbangan tertentu.Adapun objek dari penelitian ini adalah Kecamatan Plered di mana Kecamatan Plered tersebut merupakan sentra industri batik terbesar di Jawa Barat.

Untuk penentuan jumlah sampel dalam penelitian ini dilakukan dengan menggunankan rumus Slovin (Sugiyono, 2012) yaitu sebagai berikut :

$$
n=\frac{N}{1+N(e)^{2}}
$$

Di mana $n=$ jumlah sampel

$\mathrm{N}=$ jumlah populasi

e $=$ taraf kesalahan ditetapkan 15\% dengan tingkat kepercayaan $90 \%$

Dari rumus tersebut, maka diambil sampel dengan jumlah sebagai berikut:

Tabel 2.

Distribusi Sampel Tenaga Kerja

\begin{tabular}{|c|l|c|c|}
\hline No & \multicolumn{1}{|c|}{ Nama Desa } & $\begin{array}{c}\text { Populasi } \\
(\mathbf{N})\end{array}$ & $\begin{array}{c}\text { Jumlah } \\
\text { Sampel (n) }\end{array}$ \\
\hline 1. & Trusmi Kulon & 450 & 22 \\
\hline 2. & Trusmi Wetan & 200 & 10 \\
\hline 3. & Panembahan & 120 & 6 \\
\hline 4. & Gamel & 40 & 2 \\
\hline 5. & Wotgali & 39 & 2 \\
\hline \multicolumn{2}{|c|}{ Jumlah } & $\mathbf{8 4 9}$ & $\mathbf{4 2}$ \\
\hline
\end{tabular}

\section{Variabel Penelitian dan Definisi Operasional Variabel}

Variabel dalam penelitian ini terdiri dari dua macam variabel yaitu variabel dependen dan variabelindependen. Menurut Sugiyono (2012) variabel dependen (terikat) adalah variabel yang dipengaruhi atau yang menjadi akibat, karena adanya variabel independen (bebas). Sedangkan variabel independen (bebas) adalah variabel yang memengaruhi atau yang menjadi sebab perubahannya atau timbulnya variabel dependen (terikat).

Adapun definisi dari variabelvariabel tersebut diatas dijelaskan didalam bentul tabel sebagai berikut:

Tabel 3.

Definisi operasional

\begin{tabular}{|c|c|c|}
\hline Variabel & Definisi & Parameter \\
\hline $\begin{array}{l}\text { Jumlah } \\
\text { Tanggunga } \\
\mathrm{n} \text { Keluarga } \\
(\mathrm{X} 1)\end{array}$ & $\begin{array}{l}\text { Jumlah } \\
\text { tanggungan } \\
\text { keluarga } \\
\text { menunjukkan } \\
\text { banyaknya orang } \\
\text { yang ditanggung } \\
\text { oleh kepala } \\
\text { keluarga }\end{array}$ & $\begin{array}{l}\text { 1. Istri } \\
\text { 2. Anak } \\
\text { 3. Orang } \\
\text { tua } \\
\text { 4. Orang } \\
\text { lain } \\
\text { yang } \\
\text { tinggal } \\
\text { seruma } \\
\text { h/diluar } \\
\text { rumah } \\
\text { tetapi } \\
\text { menjadi } \\
\text { tanggu } \\
\text { ngan }\end{array}$ \\
\hline $\begin{array}{l}\text { Lama Kerja } \\
\text { Perhari (X2) }\end{array}$ & $\begin{array}{l}\text { Jumlah jam kerja } \\
\text { seseorang pada } \\
\text { saat bekerja dalam } \\
\text { satu hari }\end{array}$ & Jam \\
\hline $\begin{array}{l}\text { Lama Kerja } \\
\text { Perbulan } \\
\text { (X3) }\end{array}$ & $\begin{array}{l}\text { Jangka waktu yang } \\
\text { telah } \\
\text { seseorang dilalui }\end{array}$ & Hari \\
\hline
\end{tabular}




\begin{tabular}{|c|c|c|}
\hline & $\begin{array}{l}\text { menekuni } \\
\text { pekerjaan }\end{array}$ & \\
\hline $\begin{array}{l}\text { Pengalama } \\
\text { n Bekerja } \\
(\mathrm{X} 4)\end{array}$ & $\begin{array}{l}\text { Tingkat } \\
\text { penguasaan, } \\
\text { pengetahuan serta } \\
\text { ketrampilan } \\
\text { seseorang dalam } \\
\text { pekerjaanya }\end{array}$ & Tahun \\
\hline $\begin{array}{l}\text { Jumlah } \\
\text { Produksi } \\
\text { (X5) }\end{array}$ & $\begin{array}{l}\text { Setiap } \\
\text { kegiatan/usaha } \\
\text { seseorang untuk } \\
\text { menghasilkan atau } \\
\text { menambah guna } \\
\text { barang }\end{array}$ & Jam \\
\hline $\begin{array}{l}\text { Biaya } \\
\text { operasiona } \\
\text { I yang } \\
\text { dikeluarka } \\
\text { n (X6) }\end{array}$ & $\begin{array}{l}\text { Seluruh } \\
\text { pengorbanan yang } \\
\text { dikeluarkan oleh } \\
\text { tenaga kerja batik } \\
\text { untuk mendanai } \\
\text { kegiatan untuk } \\
\text { mencapai tujuan }\end{array}$ & Rupiah \\
\hline $\begin{array}{l}\text { Tingkat } \\
\text { Upah } \\
\text { Tenaga } \\
\text { Kerja } \\
\text { Industri } \\
\text { Batik (Y) }\end{array}$ & $\begin{array}{l}\text { Merupakan upah } \\
\text { yang diterima } \\
\text { tenaga kerja industri } \\
\text { batik yang } \\
\text { bersih/ah } \\
\text { dikurangi } \\
\text { operasional. }\end{array}$ & Rupiah \\
\hline
\end{tabular}

\section{Prosedur Pengumpulan Data}

Dalam penelitian ini penulis mengumpulkan data dengan teknik sebagai berikut:

1. Kuisioner, yaitu dengan menyebarkan kuisioner kepada responden untuk memperoleh data yang berhubungan dengan penelitian kepada tenaga kerja unit rumahan yang ada di Kecamatan Plered

2. Observasi, yaitu dengan mendatangi dan mengamati langsung tempat penelitian untuk memperoleh informasi yang berkaitan dengan penelitian.

\section{Analisis Data \\ Regresi Berganda}

Analisis Regresi merupakan suatu analisis mengenai suatu pengaruh antara variable bebas dengan variable terikat. Analisis regresi yang melibatkan satu variable bebas dan satu variable terikat disebut dengan analisis linier sederhana. Dan jika analisis melibatkan satu variable terikat dengan lebih dari satu variable bebas maka disebut dengan analisis regresi linier berganda. Dalam penelitian ini metode yang yang digunakan yaitu analisis regresi regresi linier berganda. Berikut persamaan regresi linier bergandanya:

$$
Y=a+\beta_{1} X_{1}+\beta_{2} X_{2}+\beta_{3} X_{3}+\beta_{4} X_{4}+\beta_{5} X_{5}+\beta_{6}
$$

$X_{6}+\varepsilon$

Di mana:

$$
\begin{aligned}
\mathrm{Y} & =\text { Tingkat upah tenaga kerja industri batik } \\
\mathrm{X} 1 & =\text { Jumlah tanggungan keluarga } \\
\mathrm{X} 2 & =\text { Lama kerja perhari } \\
\mathrm{X} 3 & =\text { Lama kerja perbulan } \\
\mathrm{X} 4 & =\text { pengalaman bekerja } \\
\mathrm{X} 5 & =\text { Jumlah produksi } \\
\mathrm{X} 6 & =\text { biaya operasional } \\
\beta_{1} \beta_{2} \beta_{3} & =\text { Koefisien masing-masing variable } \\
\mathbf{a} & =\text { Konstanta } \\
\varepsilon & =\text { galat }
\end{aligned}
$$

\section{Uji Asumsi Klasik}

Uji asumsi klasik digunakan untuk mengetahui ketepatan data. Menurut Santoso (2009: 342) "Sebuah model regresi akan digunakan untuk melakukan keramalan sebuah model yang baik adalah model dengan kesalahan peramalan yang seminimal mungkin. Karena itu, sebuah model sebelum digunakan seharusnya memenuhi 
Hartono/Jurnal Ekonomi Syariah Teori dan Terapan Vol. 6 No. 4 April 2019: 861-879; ANALISIS EKONOMI ISLAM TERHADAP PEMENUHAN UPAH LAYAK TENAGA KERJA INDUSTRI BATIK (STUDI KASUS : SENTRA BATIK KECAMATAN PLERED KABUPATEN CIREBON)

beberapa asumsi, yang biasa disebut asumsi klasik." Dalam penelitian ini uji asumsi klasik yang digunkan adalah: uji normalias, uji autokorelasi, uji multikolinearitas, dan uji heterokedastisitas.

\section{HASIL DAN PEMBAHASAN}

\section{Model Matematika Pemenuhan Upah}

Layak

Penelitian ini terdapat enam variabel bebas $(X)$ yaitu $X_{1}$ (jumlah tanggungan) $X_{2}$ (lama kerja perhari) $X_{3}$ (lama kerja perbulan) $X_{4}$ (pengalaman bekerja) $X_{5}$ (jumlah produksi) $X_{6}$ (biaya operasional) dan varibel terikatnya (Y) adalah tingkat upah tenaga kerja industri batik.

Hasil analisis regresi linier berganda digunakan untuk mengetahui pengaruh beberapa variabel bebas terhadap tingkat upah tenaga kerja industri batik, model yang diperoleh dari industri batik adalah sebagai berikut:

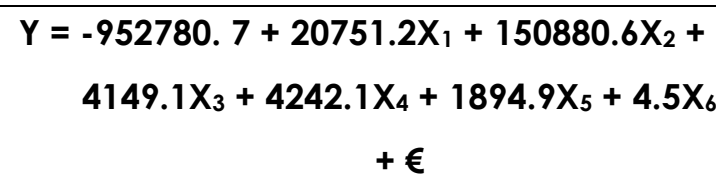

Berdasarkan hasil uji nilai koefisien determinasi (lihat Tabel 4.11) diperoleh nilai R2 sebesar 0.428 atau $42,8 \%$. Artinya bahwa tingkat upah tenaga kerja industri batik dipengaruhi oleh variabel bebas sebesar $42,8 \%$ dan sisanya $57,2 \%$ dipengaruhi oleh variabel lainnya.

Terdapat tiga variabel yang berpengaruh secara signifikan terhadap tingkat upah berdasarkan taraf signifikansi $<0,10$ yaitu variabel lama kerja perhari, pengalaman bekerja dan biaya operasional. Hal ini menunjukkan bahwa lama kerja perhari berdasarkan analisis parsial secara statistik berpengaruh nyata pada taraf $10 \%$ yang berarti faktor ini mempengaruhi tingkat upah tenaga kerja secara signifikan. Hasil analisis menunjukkan tanda koefisien lama kerja perhari bernilai positif yaitu 0,000 yang berarti bahwa semakin lama jam kerja seorang pekerja pembatik maka jumlah produksi dalam sehari akan meningkat, karena upah yang diterima berdasarkan jumlah kain yang telah dibatik. Sedangkan pengalaman bekerja berdasarkan analisis parsial variabel pengalaman bekerja secara statistik berpengaruh nyata pada taraf $10 \%$ yang berarti faktor ini mempengaruhi tingkat upah tenaga kerja secara signifikan.

Hasil analisis menunjukkan tanda koefisien pengalaman bekerja bernilai positif yaitu 0,48 . Ini menunjukkan bahwa pengalaman bekerja akan mempengaruhi tingkat upah tenaga kerja industri batik unit rumahan, dikarenakan setiap 1 tahun sekali pekerja akan mendapat bonus berupa upah yang meningkat, dan juga menambah pengetahuan dalam membatik. Adapun variabel biaya operasional berpengaruh signifikan terhadap tingkat upah tenaga kerja industri batik unit rumahan pada taraf 10\%. Hasil analisis menunjukkan tanda koefisien biaya operasional bernilai positif yaitu 0,080 . Ini mengartikan bahwa semakin sedikit biaya operasional yang dikeluarkan oleh tenaga kerja maka akan 
semakin tinggi tingkat upah tenaga kerja industri batik unit rumahan tersebut. Variabel biaya operasional dalam industri batik ini seperti kain dan lilin sudah ditanggung oleh pihak industri, namun biaya lainnya seperti bahan bakar, canting, kompor merupakan tanggungjawab pekerja. Selain itu ketika pekerja tidak bisa menyelesaikan pekerjaannya dikarenakan lilin yang digunakan kurang, maka lilin tersebut harus dibeli dan itu sudah menjadi tanggungjawab pekerja. Jadi biaya operasional yang dikeluarkan oleh pihak tenaga kerja unit rumahan industri batik akan mempengaruhi tingkat upah yang didapatkan. Adapun dalam pandangan ekonomi islam terhadap sistem pengupahan tenaga kerja unit rumahan industri batik.

\section{Pandangan Ekonomi Islam Terhadap} Sistem Pengupahan Tenaga Kerja Unit Rumahan Industri Batik

Upah dalam pengertian islam (ujrah) merupakan imbalan atau balasan yang menjadi hak bagi buruh atau pekerja karena telah melakukan pekerjaannya. Akad ijarah dalam alQur'an maupun Sunnah telah memberikan perintah kepada manusia untuk bekerja atau berusaha secara maksimal sehingga mendapat balasan sesuai dengan apa yang telah dikerjakannya, baik dalam ibadah ataupun muamalah. Dalam arti yang luas upah dikategorikan kedalam wilayah ijarah. ljarah dapat dibedakan menjadi dua macam, yaitu ijarah yang bersifat manfaat dan ijarah yang bersifat pekerjaan. ljarah manfaat adalah akad dimana pihak pertama mengambil manfaat benda dari pihak kedua dengan batasan-batasan tertentu dan pihak kedua akan mendapatkan imbalan berupa upah tertentu pula. Taqyudin anNabhani memberikan pengertian bahwa yang dimaksud dengan ijarah adalah kepemilikan jasa dari seorang ajir (orang yang dikontrak tenaganya) serta pemilikan harta mustajir oleh orang ajir, dimana ijarah merupakan transaksi terhadap jasa tertentu dengan disertai kompensasi yang berupa imbalan. Sementara menurut sudarso, membagi ijarah menjadi dua jenis yaitu, pertama ijara al a'yan adalah bahwa yang menjadi objeknya adalah manfaat dari benda atau binatang yang disewanya, sedangkan ijarah al "amal adalah ijarah bahwa yang objeknya adalah dari pekerjaan manusia.

Al-Qur'an dengan tegas telah memberikan perintah bahwa balasan atau upah harus diberikan kepada yang berhak menerimanya. Upah harus diberikan secara adil dan tidak merugikan salah satu pihak. Adil secara bahasa mengandung dua arti, tidak berat sebelah (tidak memihak) dan sepatutnya, tidak sewenang-wenang. Keadilan sosial dalam islam ditegakkan berdasarkan pada 3 asas, yaitu: Kebebasan jiwa yang mutlak, Perasaan kemanusian yang sempurna, Jaminan sosial yang kuat. 
Hartono/Jurnal Ekonomi Syariah Teori dan Terapan Vol. 6 No. 4 April 2019: 861-879; ANALISIS EKONOMI ISLAM TERHADAP PEMENUHAN UPAH LAYAK TENAGA KERJA INDUSTRI BATIK (STUDI KASUS : SENTRA BATIK KECAMATAN PLERED KABUPATEN CIREBON)

Pada dasarnya dalam pola masyarakat islam, pengupahan bukan hanya merupakan suatu konsesi, akan tetapi merupakan hak bagi para buruh/pekerja yang dalam penetapannya harus memenuhi 3 asas, yaitu asas keadilan, asas kelayakan dan asas kebajikan.

\section{a. Prinsip Keadilan}

Seorang pengusaha tidak diperkenankan bertindak kejam terhadap buruh dengan menghilangkan hak sepenuhnya dari bagian mereka. Upah itetapkan dengan cara yang paling tepat tanpa harus menindas pihak manapun, setiap pihak memperoleh bagian yang sah dari hasil kerja sama mereka tanpa adanya ketidakadilan terhadap pihak lain. Upah kerja minimal dapat memenuhi kebutuhan pokok dengan ukuran taraf hidup lingkungan masyarakat sekitar. Keadilan berarti menuntut upah kerja yang seimbang dengan jasa yang diberikan buruh.

Adil mempunyai bermacammacam makna, di antaranya sebagai berikut:

1. Adil bermakna jelas dan transparan, dapat diketahui bahwa prinsip utama keadilan terletak pada Kejelasan aqad (transaksi) dan komitmen melakukannya. Aqad dalam perburuhan adalah aqad yang terjadi antara pekerja dengan pengusaha. Artinya, sebelum pekerja dipekerjakan, harus jelas dahulu bagaimana upah yang akan diterima oleh pekerja. Upah tersebut meliputi besarnya upah dan tata cara pembayaran upah.

2. Adil bermakna proporsional, pekerjaan seseorang akan dibalas menurut berat pekerjaannya itu. Upah adalah hak dan bukan pemberian sebagai hadiah. Upah hendaklah proporsional, sesuai dengan kadar kerja atau hasil produksi dan dilarang adanya eksploitasi.

\section{b. Prinsip Kelayakan}

Kelayakan menuntut agar upah kerja cukup untuk memenuhi kebutuhan hidup minimum secara layak, Adapun layak mempunyai makna sebagai berikut:

1. Layak bemakna cukup pangan, sandang, dan papan.

2. Layak bermakna sesuai dengan pasaran.

Dalam pengertian yang lebih jauh, hak-hak dalam upah bermakna bahwa janganlah memperkerjakan seseorang jauh di bawah upah yang biasanya diberikan.

\section{c. Prinsip Kebajikan}

Menghargai jasa satu sama lain, dimana pihak tenaga telah memberikan tenaga kemampuannya untuk memperoleh kekayaan yang lebih bagi pihak industri dan pihak industri telah memberikan pekerjaan untuk pekerja.

Namun jika dilihat dari segi penetapan hukum, dalam islam juga mengenal dengan namanya 'urf. Islam sangat memperhatikan tradisi masyarakat untuk dijadikan sumber bagi hukum islam dengan penyempurnaan dan batasanbatasan tertentu. Secara etimologi berarti 
'urf 'yang baik'. Para ulama ushul fiqh membedakan antara adat dan "urf dalam membahas kedudukannya sebagai salah satu dalil untuk menetapkan hukum syara'. Dari segi keabsahannya dari pandangan syara', 'urf terbagi dua, yaitu 'urf al-sahih (kebiasaan yang dianggap sah) dan 'urfal-fasid (kebiasaan yang dianggap rusak).

\section{1. 'Urf al-sahih}

Adalah kebiasaan yang berlaku ditengah-tengah masyarakat yang tidak bertentangan dengan ayat AlQur'an ataupun hadist, tidak menghilangkan kemaslahatan mereka, dan tidak pula membawa mudharat kepada mereka.

2. 'Urfal-fasid

Adalah kebiasaan yang bertentangan dengan dalil-dalil syara' dan kaidahkaidah dasar yang ada dalam syara'. Misalnya kebiasaan yang berlaku dikalangan masyarakat dalam menghalalkan riba, seperti peminjaman vang renteiner. Uang yang dipinjam sebesar sepuluh juta rupiah dalam tempo satu bulan, harus dibayar sebelas juta rupiah apabila jatuh tempo.

Dalam hal ini upah yang dilakukan oleh pihak industri menggunakan sistem yang sudah menjadi adat kebiasaan didaerah tersebut. 'Urf yang berlaku ditengah-tengah masyarakat adakalanya bertentangan denagn nash dan adakalanya bertentang dengan dalil syara' lainnya. Dalam hal ini pembayaran upah yang sudah menjadi kebiasaan yang terjadi di industri batik unit rumahan ini bahwa kebiasaan ini tidak menyebabkan nash menjadi tidak berfungsi. Maka 'urf (kebiasaan) yang terjadi bisa dijadikan landasan hukum.

Menurut Tjiptoherijanto (2001), masalah industrial telah sejak lama menjadi masalah yang kompleks danberkepanjangan. Hal tersebut terjadi karena tidak terjalinnya keserasian hubungankerja antara pekerja atau buruh dengan pengusaha. Kasus ini sering dijumpaikarena mayoritas pekerja tidak puas terhadap sistem pengupahan yang ada, dimana pekerja berkepentinganterhadap tingkat upah yang mereka harapkan, sedangkan pengusaha berusahamelakukan efisiensi biaya guna memaksimumkan laba dan returns kepadapemegang saham sehingga perlu diciptakan hubungan selaras antara kepentinganpekerja dan pengusaha.

Tentunya dapat disepakati bahwa upah merupakan sumber penghasilan guna memenuhi kebutuhan diri si pekerja dan cerminan kepuasan kerja. Sementara bagi pemilik indusri melihat upah sebagai bagian dari biaya produksi, sehingga harus dioptimalkan penggunaannya dalam meningkatkan produktivitas dan etos kerja. Disisi lain pemerintah memandang upah sebagai suatu imbalan disatu pihak untuk tetap dapat menjamin terpenuhinya kehidupan yang layak bagi 
Hartono/Jurnal Ekonomi Syariah Teori dan Terapan Vol. 6 No. 4 April 2019: 861-879; ANALISIS EKONOMI ISLAM TERHADAP PEMENUHAN UPAH LAYAK TENAGA KERJA INDUSTRI BATIK (STUDI KASUS : SENTRA BATIK KECAMATAN PLERED KABUPATEN CIREBON)

pekerja dan keluarganya, meningkatkan produktivitas pekerja dan meningkatkan daya beli masyarakat. Dipihak lain, untuk mendorong kemajuan dan daya saing usaha.

Kebijakan ketenagakerjaan sudah diatur oleh Pemerintah terutama menyangkut penanganan pengupahan yang disebut Kebutuhan Hidup Layak (KHL). Berkaitan dengan kebutuhan kehidupan layak pekerja, maka tidak akan lepas dari permasalahan upah. Saat ini pelaksanaan pembayaran upah yang diberikan kepada pekerja unit rumahan terbilang sangat minim dan juga terjadinya ketidak keadilan dalam pembayaran yakni terjadi keterlambatan dalam pengupahan.

Berdasarkan Upah Minimum Kerja (UMK) Kabupaten Cirebon tahun 2016, diperoleh sebuah keterangan bahwa gaji atau upah minimum Kabupaten Cirebon adalah $\mathrm{Rp}$ 1.592.220,-. Formulasi lain dalam mendefinisikan upah dapat dilihat dari Peraturan Pemerintah Indonesia selalu berubah-ubah kebijakan ketenagakerjaannya terutama menyangkut penanganan pengupahan. Kebijakan penentuan upah minimum didasarkan pada Kebutuhan Fisik Minimum (KFM), yang kemudian berubah menjadi Kebutuhan Hidup Minimum (KHM), lalu sekarang namanya menjadi pencapaian $(\mathrm{KHL})$. Seperti yang telah diamanatkan dalam Pasal 89 ayat (2) Undang-Undang Nomor 13 Tahun 2003 tentang ketenagakerjaan.
Sementara itu, kaitannya dengan Kebutuhan Hidup Layak, dapat dilihat dari Pasal 88 ayat (1) Undang-Undang yang sama yang menegaskan bahwa setiap pekerja berhak memperoleh penghasilan yang memenuhi penghidupan yangmemenuhi penghidupan yang layak bagi kemanusiaan. Berikut gambar model pengupahan yang layak:

\section{Model Model Pengupahan yang Layak Pada Industri Batik}

Menurut Tjiptoherijanto (2001), masalah industrial telah sejak lama menjadi masalah yang kompleks danberkepanjangan. Hal tersebut terjadi karena tidak terjalinnya keserasian hubungan kerja antara pekerja atau buruh dengan pengusaha. Kasus ini sering dijumpaikarena mayoritas pekerja tidak puas terhadap sistem pengupahan yang ada, dimana pekerja berkepentinganterhadap tingkat upah yang mereka harapkan, sedangkan pengusaha berusahamelakukan efisiensi biaya guna memaksimumkan laba dan returns kepadapemegang saham sehingga perlu diciptakan hubungan selaras antara kepentinganpekerja dan pengusaha.Tentunya dapat disepakati bahwa upah merupakan sumber penghasilan guna memenuhi kebutuhan diri si pekerja dan cerminan kepuasan kerja.Sementara bagi pemilik indusri melihat upah sebagai bagian dari biaya produksi, sehingga harus dioptimalkan penggunaannya dalam meningkatkan produktivitas dan etos kerja. Di sisi lain 
pemerintah memandang upah sebagai suatu imbalan disatu pihak untuk tetap dapat menjamin terpenuhinya kehidupan yang layak bagi pekerja dan keluarganya, meningkatkan produktivitas pekerja dan meningkatkan daya beli masyarakat. Dipihak lain, untuk mendorong kemajuan dan daya saing usaha.

Kebijakan ketenagakerjaan sudah diatur oleh Pemerintah terutama menyangkut penanganan pengupahan yang disebut Kebutuhan Hidup Layak $(\mathrm{KHL})$. Berkaitan dengan kebutuhan kehidupan layak pekerja, maka tidak akan lepas dari permasalahan upah. Saat ini pelaksanaan pembayaran upah yang diberikan kepada pekerja unit rumahan terbilang sangat minim dan juga terjadinya ketidak keadilan dalam pembayaran yakni terjadi keterlambatan dalam pengupahan.Berdasarkan Upah Minimum Kerja (UMK) Kabupaten Cirebon tahun 2016, diperoleh sebuah keterangan bahwa gaji atau upah minimum Kabupaten Cirebon adalah Rp 1.592.220,-. Formulasi lain dalam mendefinisikan upah dapat dilihat dari Peraturan Pemerintah Indonesia selalu berubah-ubah kebijakan ketenagakerjaannya terutama menyangkut penanganan pengupahan. Kebijakan penentuan upah minimum didasarkan pada Kebutuhan Fisik Minimum (KFM), yang kemudian berubah menjadi Kebutuhan Hidup Minimum (KHM), lalu sekarang namanya menjadi pencapaian (KHL).Seperti yang telah diamanatkan dalam Pasal 89 ayat (2) Undang-Undang Nomor 13 Tahun 2003 tentang ketenagakerjaan. Sementara kaitannya dengan Kebutuhan Hidup Layak, dapat dilihat dari Pasal 88 ayat (1) Undang-Undang yang sama yang menegaskan bahwa setiap pekerja berhak memperoleh penghasilan yang memenuhi penghidupan yang memenuhi penghidupan yang layak bagi kemanusiaan. Berikut gambar model pengupahan yang layak:

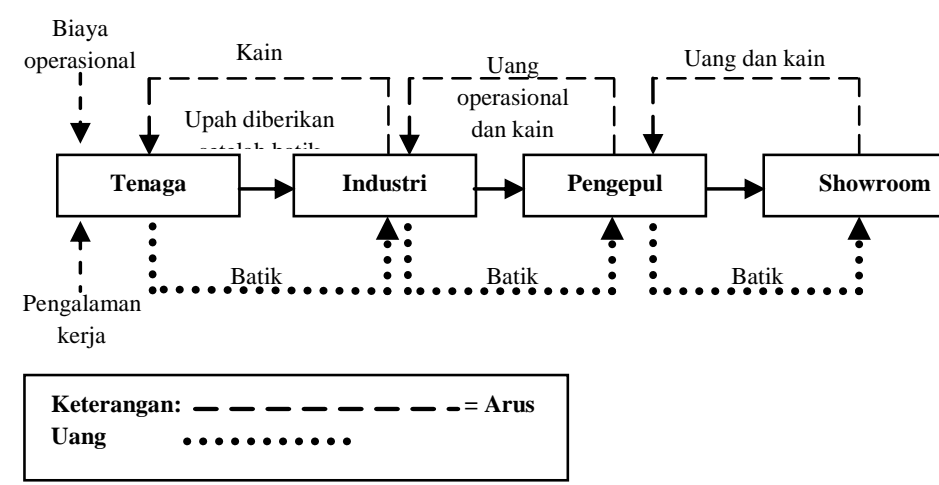

Sumber: Data primer diolah (2016)

\section{Gambar 1.}

\section{Model Pengupahan yang layak}

Bagi masyarakat Kecamatan Plered, kegiatan membatik merupakan aktivitas yang sudah tak asing lagi dan sudah menjadi budaya membatik bagi masyarakat sekitar. Dilihat dengan banyak berdirinya industri batik memberi dampak yang cukup positif terhadap perekonomian masyarakat sekitar karena dapat memberi peluang kerja. Peluang tersebut tidak disia-siakan oleh masyarakat sekitar, dilihat dari banyaknya yang bekerja di industri tersebut. Sebelum membahas bagaimana proses membatik 
Hartono/Jurnal Ekonomi Syariah Teori dan Terapan Vol. 6 No. 4 April 2019: 861-879; ANALISIS EKONOMI ISLAM TERHADAP PEMENUHAN UPAH LAYAK TENAGA KERJA INDUSTRI BATIK (STUDI KASUS : SENTRA BATIK KECAMATAN PLERED KABUPATEN CIREBON)

terlebih kita akan mengetahui untuk membuat 1 kain batik cap pihak industri harus menyelesaikan dalam waktu 2-3 hari, selanjutnya proses pembuatan batik yakni bermula dari showroom batik yang memberikan modal berupa uang dan kain yang diserahkan kepengepul, lalu pengepul tersebut menyerahkan modal berupa bahan dan vang (untuk proses produksi belum sepenuhnya dikasih) kepihak industri, setelah itu pihak industri membuat desain batik dengan menggunakan bolpen, selanjutnya bahan tersebut diserahkan kepihak tenaga kerja, tenaga kerja mendapat barang berupa kain yang telah digambar untuk dibatik menggunakan lilin. Setelah kain sudah dibatik maka pekerja langsung menyetornya ke pihak industri, selanjutnya pihak industri akan mengolah kembali batik tersebut dengan memberi warna dan setelah itu siap untuk dijual. pihak industri akan menyerahkan batik yang sudah jadi kepengepul dan mendapat imbalan berupa vang. Setelah itu pengepul akan menyerahkan kembali pesanan yang diinginkan pihak showroom batik.

Untuk pengupahan yang diterima oleh pihak tenaga kerja industri sendiri, besaran upahnya dilihat dari pengangalaman bekerja, lama kerja dalam sehari dan biaya operasional. Namun ketika biaya operasional dimasukkan dalam tanggungjawab pekerja maka pihak industri harus lebih memperhatikan lagi dikarenakan biaya operasional yang dikeluarkan oleh pekerja semakin lama akan mengalami kenaikan pula. Jika dilihat dari teori biaya produksi adalah sebagian atau keseluruhan faktor produksi yang dikorbankan dalam proses produksi untuk menghasilkan suatu produk barang. Dalam rencana kegiatan usaha, biasanya biaya produksi dihitung berdasarkan jumlah produk yang sudah siap jual. Biaya produksi sering disebut ongkos produksi. Secara umum, biaya produksi didefinisikan sebagai keseluruhan biaya yang dikorbankan atau dikeluarkan untuk menhasilkan produk hingga produk itu sudah siap jual. Tetapi pada kenyataan yang terjadi dilapangan biaya produksi harus ditanggung oleh pihak tenaga kerja.

Adapun permasalahan lain yaitu terjadi ketidak adilan seperti yang sudah dijelaskan pada pembahasan diawal, bahwasannya pekerja tidak langsung menerima upah namun sebagian pekerja harus menunggu. Di dalam islam ketika upah tersebut ditunda-tunda maka haram hukumnya. Rasulullah SAW mengibaratkan jarak waktu pemberian upah dan selesainya pekerjaan dengan keringat. Jangan sampai keringatnya mengering, artinya sesegera mungkin setelah ia menyelesaikan pekerjaannya. Tidak menunggu esok, apalagi lusa. Imam alMunawi mengatakan, seorang majikan yang menunda pemberian gaji, berarti ia sudah melakukan kezaliman kepada pekerjanya. 
Hartono/Jurnal Ekonomi Syariah Teori dan Terapan Vol. 6 No. 4 April 2019: 861-879; ANALISIS EKONOMI ISLAM TERHADAP PEMENUHAN UPAH LAYAK TENAGA KERJA INDUSTRI BATIK (STUDI KASUS : SENTRA BATIK KECAMATAN PLERED KABUPATEN CIREBON)

Berkaitan dengan penetapan
upah berdasarkan Kebutuhan Hidup Layak (KHL), Pemerintah menetapkan peraturan atau yang dikenal dengan Permenakertrans Nomor: PER17/MEN/VIII/2005 tentang Komponen dan Pelaksanaan Tahapan Pencapaian Kebutuhan Hidup Layak (KHL) sekaligus sebagai aturan dalam pelaksanaan dari Pasal 89 ayat (4) Undang-Undang Nomor 13 Tahun 2003 tentang Ketenagakerjaan yang berbunyi: Komoponen dan pelaksanaan tahapan pencapaian kebutuhan hidup layak diatur dengan Peraturan Menteri. Dalam Pasal 1 Permenakertrans Nomor: PER17/MEN/VIII/2005 misalnya disebutkan bahwa KHL adalah Standar kebutuhan yang harus dipenuhi oleh seorang pekerja atau buruh lajang untuk dapat hidup layak baik secara fisik, non fisik dan sosial untuk kebutuhan satu bulan. Komponen kebutuhan hidup layak untuk para pekerja lajang dam satu bulan sebagaimana terlampir dalam Nomor: PER17/MEN/VIII/2005 terdiri dari: makanan dan minuman, sandang, perumahan, pendidikan, kesehatan, transportasi dan rekreasi dan tabungan.Adapun dalam pandangan islam bahwa upah tidak sekedar kebutuhan lahir saja. Tetapi mereka harus mendapatkan pendidikan dan berbagai fasilitas pengobatan. Sehingga apabila upah dikaitkan dengan apa yang telah difasilitaskan atau sesuai kebutuhan minimalnya adalah sangat tidak tepat karena akan menghalangi pekerja untuk menikmati kehidupan yang layak menurut ukuran masyarakat.

\section{SIMPULAN}

1. Upah yang diterima pekerja industri batik unit rumahan terbilang tidak layak dan juga dalam pemberian upahnya terjadi keterlambatan yang dilakukan pemilik industri batik, dilihat secara hukum islam merupakan kesalahan yang dilakukan pihak industri batik terhadap pekerjanya. Apa yang menjadi kewajiban pemilik industri dan hak bagi pekerja tidak terlaksana. Namun apa yang terjadi tidak sepenuhnya kesalahan yang dilakukan pemilik industri, karena dalam sistem pengupahannya melibatkan pengepul. Dan pihak pekerjapun tidak menuntut dengan apa yang terjadi, karena telah ada kepastian diantara kedua belah pihak, dan mereka sudah yakin dengan upah yang pastinya akan diterima juga.

2. Sistem pemberian upah kepada pekerja unit rumahan dapat dikategorikan dalam ajir'am, karena bekerja pada pengusaha tertentu dan hanya diikat oleh upah yang didasarkan atas hasil kerjanya, karena upah yang diberikan oleh industri batik kepada pekerjanya berdasarkan berapa banyak mereka menghasilkan kain yang telah dibatik dalam setiap harinya.

3. Model pengupahan yang layakpada industri batik unit rumahan Kecamatan Plered harus memperhatikan aspek 
waktu pembayaran, biaya operasional dan pengalaman bekerja. Ketika biaya operasional mengalami kenaikan seharusnya upah membatik juga naik, namun hal tersebut tidak terjadi.

\section{DAFTAR PUSTAKA}

Daniyah, Hamidah. 2013. Pengaruh Dana Pihak Ketiga dan Non Performing Loan Terhadap Penyaluran Kredit (PT.Bank ICB Bumiputera., Tbk). Skripsi. Universitas Pendidikan Indonesia.http://repository.upi.edu /2321/6/S_PEM_0901069_Chapter3. pdf. [2/2/2016]

Dinas Perindustrian dan Perdagangan Kabupaten Cirebon. 2011. Jumlah Tenaga Kerja Industri Batik. Cirebon.

Hafidh Abdul, R. 2010.Hadis Tentang Waktu Pembayaran Upah (Studi Sanad Dan Matan). Skripsi.Jurusan Tafsir Hadis Fakultas Ushuluddin Studi Agama Dan Pemikiran Islam Universitas Islam Negeri Sunan Kalijaga Yogyakarta. [28/1/2016]

Mustofa, Muhammad. 2009. Tinjauan Hukum Islam Terhadap Upah Minimum Pasal 1 Ayat 1 dan 2 dalam PERMENAKERTRANS Nomor: PER-17/MEN/VIII/2005.

Skripsi.Universitas Islam Negeri Sunan Kalijaga Yogyakarta.

Nasir, Nadia. 2008. Analisa Pengaruh Tingkat Upah, Masa Kerja, Usia Terhadap Produktivitas Tenaga Kerja (Studi Kasus Pada Tenaga Kerja Perusahaan Roko "Djagung
Padi" Malang). Skripsi. Jurusan Ekonomi Pembangunan Fakultas Ekonomi Universitas Brawijaya Malang.[28/1/2016]

Nazir Moh. 1988. Metode Penelitian, Ghalia Indonesia, Jakarta.

Sa'adah, Ai. 2014. Analisis Kelayakan Komponen Kebutuhan Hidup Layak dalam Menggambarkan Pemenuhan Kebutuhan Hidup Pekerja/Buruh di PT ASPEX KUMBONG.Skripsi.Institut Pertanian Bogor. [28/1/2016].

Santoso Singgih. 2009. Menguasai Statistik Di Era Informasi Dengan SPSS, Jakarta, PT. Elex Media Komputindo.

Sugiyono. 2012. Metode Penelitian Kuantitatif Kualitatif dan R\&D, Bandung: Alfabeta.

Tjiptoherijanto, Prijono. 2001. Proyeksi Penduduk, Angkatan Kerja, Tenaga Kerja, dan Peran Serikat Pekerja dalam Peningkatan Kesejahteraan. Majalah Perencanaan Pembangunan. Edisi 23.

Undang- Undang Dasar Republik Indonesia Nomor 13 Tahun 2003 ayat (4) tentang ketenagakerjaan. Undang- Undang Dasar Republik Indonesia Nomor 13 Tahun 2003 Pasal 88 ayat (1) tentang Kebutuhan Hidup Layak (KHL). 